\title{
Private Armies in Contemporary International Politics
}

\author{
Ass. Prof. Dr. Bujar Ahmedi \\ MSc. Besian Ahmeti \\ State University Tetovo - Macedonia, Law Faculty
}

\begin{abstract}
The use of mercenaries has been historically a constant phenomenon till almost the end of the XX century, when their activities were criminalized by the international community. Although the age-old profession of being a mercenary may be as old as the history of warfare itself, we are perhaps witnessing a 'golden age' for the soldier of fortune. Since the end of the Cold War, there has been a proliferation of mercenary activity across the globe. Today's modern mercenary cohorts, the 'private military companies' (PMCs) that pursue their services the world over, have become big business. Since 2004, the total net worth of publically traded PMCs, excluding some less legitimate enterprises, exceeded $\$ 100 \mathrm{bn}$ globally. Despite the prolonged economic malaise post-2008, the private security sector has maintained an impressive upward pattern of growth. This emergence of the PMC as a key security actor within conflicts and regions of instability around the world has strengthened the age-old academic interest in the affairs of the mercenary.
\end{abstract}

Keywords: Cold war, conflicts, international community, private armies, international politics etc.

\section{Introduction}

The use of mercenaries has been historically a constant phenomenon till almost the end of the XX century, when their activities were criminalized by the international community. Although the age-old profession of being a mercenary may be as old as the history of warfare itself, we are perhaps witnessing a 'golden age' for the soldier of fortune. Since the end of the Cold War, there has been a proliferation of mercenary activity across the globe. Today's modern mercenary cohorts, the 'private military companies' (PMCs) that pursue their services the world over, have become big business. Since 2004, the total net worth of publically traded PMCs, excluding some less legitimate enterprises, exceeded $\$ 100 \mathrm{bn}$ globally. Despite the prolonged economic malaise post-2008, the private security sector has maintained an impressive upward pattern of growth. This emergence of the PMC as a key security actor within conflicts and regions of instability around the world has strengthened the age-old academic interest in the affairs of the mercenary.

Contrary to mercenaries, private military and security companies are legally registered transnational corporations which obtain contracts from governments, private firms, intergovernmental and non-governmental organizations. In low intensity armed conflicts or post conflict situations such as Afghanistan and Iraq their employees, contracted as civilians but armed as military personnel, operate in "grey zones" as unlawful combatants without oversight or accountability, under murky legal restraints and often with immunity.

The outsourcing of a number of basic functions which traditionally were carried out by national armies or police forces, known as the top-down privatization, has blurred the borderlines between the public services of the State and the private commercial sector. The activities of humanitarian non-profitable organizations and those of military and security transnational companies working for financial gain are also being blurred. Private military corporations often provide security and protection to humanitarian non-governmental organizations in conflict or post-conflict areas where it has become difficult for the population to distinguish them from the national armies or police forces. Humanitarian assistance risks becoming associated with an intervening armed force represented by private military and security guards. Furthermore, these PMCs do not hesitate to present themselves as peace organizations and utilize the aims of humanitarian non-profit organizations to advertise their activities. 
PMCs fill the vacuum mainly left in three types of unstable situations:

I. in zones of low-intensity armed conflict (the new asymmetrical wars) where the armies are not fully deployed or in post conflict situations with a high level of insecurity;

II. in armed conflicts when international organizations do not intervene; and

III. in troubled areas in developing countries where there is no presence of the State and extractive transnational corporations operate.

Under the emergent system of international criminal law, the individual is a subject of the law. Mercenary, like terrorism, has become an international crime. If at the international and regional level there are specific provisions regarding mercenarism and a definition of what a mercenary is, there is no definition or references to these new non-state actors which are the PMCs.

\section{PRIVATE MILITARY COMPANIES (PMC)}

\subsection{Private Military Companies}

As mentioned before, from antiquity until today, mankind has always been engaged into wars, and as long as there are wars, there will be soldiers and out of soldiers, there must be mercenaries. From the formation of the French Foreign Legion in the XIXcentury and on, the urge to form far more sophisticated mercenary armies with air craft and marine became inevitable. All of this, led into the corporate transformation.

Although the man who first formed this industry by founding WatchGuard International was David Stirling, a Scottish Lard and a military man in 1960, there are some other theories that say DynCorp of United States of America was the first one, mainly because it provided "technology and logistics support" to the American Army in Korea and Vietnam since 1946.

It is universally known that the state is an organized authority which can have an army and hand over its rights to organizations to form Private Military Companies (PMC) but still under the state's sanction. The state responsibilities are elaborated by the International Law Commission under Article 5 and 8. PMC are universally accepted and answer to war crimes and sanctions just as the state army would. They operate in international or non-international conflict and can be hired by a state party for an armed conflict, by a private company to protect its operation where the conflict it's taking place or most rarely, by a non-state party for an internal armed conflict. Based on United Nations report, their industrial worth is about US $\$ 100$ billion but very much questionable if one day, all this industry is going to fade overnight. Today, there are around thirty PMCs all over the world.

\subsection{Private Military Companies' Employees}

Soldiers of fortune played a great role for the following five decades, but they were also controversial or they were largely marginalized as criminals. To avoid mercenary criminalization and violating activities, mercenaries fall under two specific international conventions. Under these conventions, apart from financing, recruiting, training and use of mercenaries being a mercenary is not a crime, and mercenarism is not engendered with criminalization but if a mercenary falls as a prisonerat-war, he will have no protection. Also, as a result of conflict and war victims, in August 12, 1949, it brought forth the demand of adding the Geneva Conventions Article 47 of Protocol I a Protection on Victims of International Armed Conflicts.

These sanctions were not entirely respected by individual mercenaries, especially by the African private armies that by 1970, their fame came into question whether private armies should exist, or how much should they be allowed to rule due to the widespread terror and crime they were imposing upon people.

Although questionable if all PMC employees are mercenaries, being a part of this industry, comes at a toll. Being under the company's uniform does not make you any different than an individual mercenary because, the mercenary's main motive is profit and being destined to kill for pay. In this case, any other motive, such as patriotism, liberty, altruism, or oppressing fall out of the mercenary category. Since PMC's main motive is profit, their very essence is also business obligated to taxation, and therefore it requests a profit with transparency, legal and moral obligations.

The more the industry was growing the higher the problems involving mercenaries and companies under the international humanitarian law became. Governments insisted on privatizing their functions to PMC asserting that these employees 
were "civilian contractors" and not combatants leaving the PMC and mercenaries accountable for their action. When cases appear, confusion always arises as to how contradictory this industry is and how the law applies and who answers to crimes if committed. Such are the two most familiar cases where it is still arguable whether the charges go to the private military companies, the state army or to the contracted individuals.

First is the case of the four Blackwater employees being killed and mutilated, and burned by Iraqi civilians in Fallujah bridge in April 2004 not having a clear distinction between a "civilian contractor" and a military one. Second is the CACl "civilian contractor" torturing Iraqi detainees in prison. United States has raised a court case for the US military personnel, but for the allegedly involved private contractors, nothing is raised so far. These two incidents have driven a discourse that the role, the status, regulations and accountability of a private military contraction must be increased by the international law.

There are also cases where even the US Intelligence Agency $(\mathrm{CIA})$ is being questioned about engaging a private contractor for war on drugs in South America against the FARC in Columbia. There is also the Sierra Leone case with Executive Outcomes Private Military Company where employees were engaged into fight with the rebels since the national forces failed. Although their case is successive, it very much poses a challenge to those who defend the international human law. In 2001, Kathryn Bolkovac brought DynCorp on court for women and girls sex trafficking after the war in Bosnia and Herzegovina. Last but not the least case of PMCs misuse, is the pleading guilty of Sir Mark Thatcher's collaborating with a private contractor to organize a coup in Equatorial Guinea without being aware what was he being involved in.

Based on what I have stated above, it can be concluded that the industry of the PMCs and its laws and regulations are complex and multifaceted.

\subsection{Theoretical approaches}

The author shall attempt to shed light on the topic of PMCs by relying on two theories, namely Realism and Security Governance theory.

Given the fundamental value attached to the notions of state centrality and the state monopoly over violent force as projected by Realism, it is perhaps comprehensible that the response to increased PMC activity in international security affairs from Realist scholars has been predominately reactionary - although we shall see this neither necessarily implies the impossibility of integrating the PMC within existing theoretical security structures nor presumes a negative outcome as a result. Whilst critics such as Peter Singer contend that the state security monopoly is only a late aberration in international affairs, it is undeniable that the existence of the PMC as an actor employed to project violence force has the potential to destabilize state-centric security structures . From a Realist perspective, the fundamental threat posed by the PMC emerges from the development of a structural 'dependence' upon the provision of security by private actors .

Contemporary security scholars from a range of theoretical disciplines have sought to engage with the PMC, many posing serious questions regarding the capacity of the PMC to contribute to international security. However, thus far critics have generally failed to undertake any cross-theoretical assessment of the PMC as a contributor to international security, with the vast majority of existing literature falling foul of a clear polemical bias either in favor of one particular theory of international security, or otherwise in general opposition to the PMC as a security actor.

Despite the ideological differences of both Realism and the Security Governance theory, both theories share a degree of similarity in their approach to the PMC; whilst Governance and Realism contain inherent bias for and against the PMC as a security actor respectively, the two theories share the view that the PMC is capable of both positively contributing and undermining existing security structures.

From the perspective of Realist scholars, the PMC is, in the first instance, a corporate entity. The very nature of the PMC invariably means that private military contractors act in the manner of a private company - it must be fiscally responsible and profitable for shareholders, and, as such, is capable of possessing an nationalistic or ideological commitment to any particular State only insofar as it complies with its first priority of making money. This in turn has a number of implications for states seeking to employ the services of PMC actors. Relying upon the services of PMC forces is inherently hazardous insofar as that it is impossible, or at least problematic, to order the individual PMC employee to act on the grounds of national loyalty or duty.

Whilst Security Governance theory similarly identifies an increasing structural dependence upon PMC services amongst state actors, Governance scholars embrace the growing integration of PMC actors into state security structures as both a 
desirable and inevitable 'delegation' of security away from the state. For Governance scholars, the increasing employment of PMC actors represents a logical decision on behalf of state actors in response to the realities of security in the post-Cold War period.

As part of this devolution of security, the PMC presents itself as a largely positive contributor to existing state-centric security structures. For Governance theorists, the widespread integration of the PMC within the military apparatus of state actors comes in the first instance as the result of a logical pursuit of economy and efficacy that echoes aspects of the Realist argument in favor of the PMC. For many states, resource scarcity presents itself as the main driver towards the economic incentive to employ PMC forces.

Whereas such success stories may appear to validate claims that the PMC can positively contribute to state-centric security, from the perspective of Realist scholars these favorable incidences are counterbalanced by the numerous cases where a dependency upon PMC actors for security has either weakened or fatally undermined state sovereignty. In regions suffering from civil strife or internecine war, employment is lucrative.

\subsection{Categories of PMC}

There is a wide range of categories that various researchers give to PMCs. Below we will provide a three-tiered classification of PMC categories based on their profile of activities:

I.

a. Operational provider - an all-purpose combat-capable military formation: insurgent suppression, country-building missions or peacekeeping,

b. Consulting provider - tactical training, organizational analysis, management, counseling and logistical support for the U.S. Army,

c. Logistical and training provider - provides supplies, shelter, meals and other base facilities for the military personnel. It can also provide repairing, rebuilding and fighting oil well fires,

d. Intellectual provider - offering intelligence personnel and equipment; surveillance and aerial mapping, photographs, videos and other network assistance,

e. Security and anti-terror provider - security and private military contractor; weapon and mine- clearance.

II.

a. Military provider firms supplying direct tactical military assistance that can include serving in front-line combat;

b. Military consulting firms that provide strategic advice and training and

c. Military support forms that provide logistics, maintenance and intelligence services to armed forces.

III.

a. Private security companies

b. Defence producers

c. Private military companies

i. Consulting

ii. Logistics and support

iii. Technical services

iv. Training

v. Peacekeeping and humanitarian assistance

vi. Combat forces 
b. Non-statutory forces and

c. Mercenaries.

This very diverse classification, serves only as an illustration to how sophisticated and complex is the combatant industry.

The overall PMC's role is not to engage in combat roles. However, over the last few decades most of the high-profile companies have engaged into a combat while in defense, or into an attack when guarding in operation. Therefore, apart from consisting security for the bases, facilities and individuals, logistical, Special Forces and intelligence gathering operations, PMC's combat role is constantly increasing.

For the sake of this thesis argument, we will be focusing on the case study of one of the most prominent representatives of the PMC world, namely Blackwater. Based on the classifications above, Blackwater falls under a many different categories, yet we will consider it as falling under the second categorization, namely as an Operational Provider.

\section{THE INTERNATIONAL LEGAL FRAMEWORK}

\subsection{Mercenaries by the UN Approach}

The immense use of mercenaries and PMC throughout history, forced the international law to come up with more detailed and specific laws for mercenaries. As mentioned in chapter III and in PMC's Employees above, the first document under the Geneva Convention of 1977 is the Article 47 of Protocol I, which explaining the term "mercenary", exempting them from the right of prisoner-at-war and prohibiting combatants to carry weapons. The second document adapted in 1989 but enforced in 2001 is the International Convention Against the Recruitment, Use, Financing and Training of Mercenaries.

Based on the Article 47 of Protocol I, the United Nations Convention:

1. A mercenary is any person who:

(a) Is specially recruited locally or abroad in order to fight in an armed conflict;

(b) Is motivated to take part in the hostilities essentially by the desire for private gain and, in fact, is promised, by or on behalf of a party to the conflict, material compensation substantially in excess of that promised or paid to combatants of similar rank and functions in the armed forces of that party;

(c) Is neither a national of a party to the conflict nor a resident of territory controlled by a party to the conflict;

(d) Is not a member of the armed forces of a party to the conflict; and

(e) Has not been sent by a State which is not a party to the conflict on official duty as a member of its armed forces.

2. A mercenary is also any person who, in any other situation:

(a) Is specially recruited locally or abroad for the purpose of participating in a concerted act of violence aimed at:

(i) Overthrowing a Government or otherwise undermining the constitutional order of a State; or

(ii) Undermining the territorial integrity of a State;

(b) Is motivated to take part therein essentially by the desire for significant private gain and is prompted by the promise or payment of material compensation;

(c) Is neither a national nor a resident of the State against which such an act is directed;

(d) Has not been sent by a State on official duty; and

(e) Is not a member of the armed forces of the State on whose territory the act is undertaken

According to this, to be a mercenary, you must meet all of the six requirements. However, two of them are the most problematic ones.

The first condition, "recruited to fight" leaves a gap into understanding that the contractor must be involved into "fighting" in order to guard a place or installation, or to defend a military objective against enemy forces regardless if its "offensive" or 
"defensive" operation. This raises the question how would the "training" that the private contractor provides will be taken. There is a specific case during the Croatian-Serbian war where the US private military company called the MPRI, was hired to plan and command the military operations to the military personnel .

The second issue is being a "neither a national of a Party to the conflict nor a resident of a territory controlled by a Party to the conflict" which also is unclear how it applies to the PMC's state and the mercenary state. When the Article 47 was adopted, the nationality issue was not a problem, but with the rise of the PMC's industry, issues like this became more evident. For instance, during the Iraq's invasion, the US PMC hired a German contractor who falls within Article 47, however, for the same issue, a British or an American co-worker, would not.

\section{2 "Civilians" and "Combatants"}

To limit civilian loss and to achieve an important side of traditional interstate relations, the international humanitarian law made a fundamental distinction between a civilian and a member of the armed forces - combatant. The international humanitarian law does not allow a "quasi-combatants" category as it has been used in some war efforts.

\subsubsection{Combatants}

By the international humanitarian law, a person who is entitled to participate or engage into hostility is called a "combatant". Furthermore, a combatant and a person protected under Geneva Convention is a:

1. members of the armed forces (including militias or volunteer corps forming part of such armed forces).

2. members of other militias and other volunteer corps, including those of organized resistance movements, operating in or outside their own territory, even if this territory is occupied, provided that they:

a. are commanded by a person responsible for his subordinates;

b. have a fixed distinctive sign recognizable at a distance;

c. carry arms openly; and

d. conduct their operations in accordance with the laws and customs of war.

3. members of regular armed forces who profess allegiance to a government or an authority not recognized by the Detaining Power.

4. persons accompanying the armed forces such as civilian members of military aircraft crews, war correspondents, supply contractors, members of labor units or of services responsible for the welfare of the armed forces.

5. members of crews, including masters, pilots and apprentices, of the merchant marine and the crews of civil aircraft.

6. Inhabitants of a non-occupied territory, who on the approach of the enemy spontaneously take up arms to resist the invading forces, without having had the time to form themselves into regular armed units, provided they carry arms openly and respect the laws and customs of war.

\subsubsection{Civilians}

A civilian is a person who has no right to what the combatant above has; has no right to engage into a hostility and no right of the Prisoner-of-War status, which would be elaborated more thoroughly below. On the other hand, since a person is either a civilian or a combatant, PMC employees are not combatants, but civilians and indeed do not have the right to participate directly in hostilities. Since, under the international humanitarian law, mercenaries do not enjoy the privilege of POW, this raises the question if PMC's employees are combatants just for the purpose to be covered within the international humanitarian law.

\subsubsection{Prisoner-of-War (POW) status}

If an army member is captured in war, he or she benefits form the official status by not getting prosecuted by the capturing state. This privilege is the "prisoner-of-war" status. The Third Geneva Convention of 1949 under the Protocol I of Article 
43 , states that there is no difference between regular armed forces and other armed groups in the combatant status. Entitled to POW status are:

1. The armed forces of a Party to the conflict consist of all organized armed forces, groups and units which are under a command responsible to that Party for the conduct of its subordinates, even if that Party is represented by a government or an authority not recognized by an adverse Party. Such armed forces shall be subject to an internal disciplinary system which, inter alia, shall enforce compliance with the rules of international law applicable in armed conflict.

2. Members of the armed forces of a Party to the conflict (other than medical personnel and chaplains ...) are combatants, that is to say, they have the right to participate directly in hostilities.

3. Whenever a Party to the conflict incorporates a paramilitary or armed law enforcement agency into its armed forces it shall so notify the other Parties to the conflict.

For this POW treaty, there are presently 164 states as a member of this party. Combatants must distinguish themselves by wearing a uniform and arms openly or else, they lose their POW status.

This status does not apply if it is a non-international conflict, usually between a government and rebels. The same applies to PMCs operating in an international armed conflict because the Protocol I of 1977 is not yet ratified by all states. Furthermore, depending on the states jurisdiction, some PMCs they hire by the state have a card that confers a certain recognition for being a state contractor in which based on Hague Regulations of 1899 and 1907, grants the POE status. Based on the above-stated combatant status for having the right to use the POW status, some interpretation of the term "belonging to a Party to the conflict" address that when a state hires the PMC, it would be required to formally incorporate them into its army domestic legislations. In that case, the state can have some "moral and legal" control" over its contractors. It is less clear when PMCs are contracted by another company if they are granted the POW status.

The privilege of the "prisoner-of-war" status does not apply to civilians as well, unless they are companion member of the military, war correspondent, supply contractors for the welfare of the armed forces and have an identity card.

\subsection{4 "Civilian" of a PMC}

If the mercenary status, the combatant and POW status do not apply to the PMCs employees, they are protected under the Geneva Convention Relative to the Protection of Civilian Persons in Time of War. PMCs member benefit of fundamental customary rules related to the prohibition of inhumane treatment, torture, hostage-taking and a right to a fair trial. They also have the right to be visited by ICRC representatives and correspond to their families. Under the security of the Detaining Power, PMCs member may be a subject to internment without a trial in an appropriate court and unlike a POW, they "shall be released by the Detaining Power as soon as the reason no longer existed."

\subsection{State Responsibilities for Hiring a PMC}

The International Law Commission prepared a norm inside Article 5 and 8 in regards to the state responsibilities for the actions of PMCs when they hire them. States should "ensure respect" for the international humanitarian law within all circumstances and when hiring a PMC, their responsibilities do not pass along to PMCs. The state must follow if PMCs are properly trained, must instruct them in the international humanitarian law, must have a legal adviser, and must contain rules of engagement.

According to the Geneva's First and Second Convention of 1949, states must publish the international human law principles to the entire population, especially to the fighting forces, medicinal personnel and the chaplains mainly by providing programs and instructions. Practically, states tend to pass it along to other actors like Red Cross societies or academic centers but when they hire PMCs, not necessarily these contractors fall under the civilian population. Generally, government would train a relevant judiciary, police and prison personnel to make sure that PMCs are trained for these laws.

To clarify this, Henckaerts and Doswald-Beck to the international humanitarian law, they added customary laws which are considered to be as a series of rules. According to these costmary laws of the international humanitarian law, number 147 states:

"A state is responsible for violations of humanitarian international law which can be attributed to it, including: 
(a) Violations committed by its organs, including its armed forces;

(b) Violations committed by persons or bodies capacitated by the state to exercise government authority;

(c) Violations committed by persons or groups acting under the instructions of the state, or under its direction or control; and

(d) Violations committed by private persons or groups which it acknowledges and adopts as its own conduct.

In addition, when PMCs commit crimes while engaged in conflicts, the states hiring them are just as responsible. For instance, the case of the International Court of Justice against Uganda while occupying Congo and the crimes private contractors committed in Ituri. The court found Uganda responsible for lack of vigilance in preventing violence under Article 43 of the Hague Regulations of 1907.

Lastly, United States had to specifically come up with similar recommendations for the PMCs operating outside the land, especially after the "Baghdad's Bloody Sunday" caused by the mercenaries of Blackwater. In September 2007, as well as in the following year, the Department of Defense and the Department of State initiated major personnel shift from another state to Iraq, and second, requested from all PMCs a daily briefing with the Department. PMCs with the Department of Defense and the Department of State signed a memorandum of agreement of procedures and policies for the PMCs personnel. The contractor's personnel are also to inform the appointed military commanders.

The U. S. and Iraq, in 2008, signed an agreement that would cover operations of armed forces when working with foreign countries. This agreement is called SOFA and it stands for a Status of Forces Agreement and it states that Iraq maintains executive criminal and jurisdiction over U.S. contractors under their employees. However, this agreement only covers PMC's contractor under United States Armed Forces, while private security personnel for protecting Embassies or military supply convoys would still be considered combatants.

In addition to this, in September 2008, the International Committee for the Red Cross and the government of Switzerland, provided the Montreux Document for monitoring the PMCs action internationally. The document holds laws of the international humanitarian law and the human rights obligations and it also holds a Global Code of Conduct for PMCs. So far, this document is signed by 34 countries.

\subsection{Other Criminal Responsibilities Connected with Mercenaries}

Violations of the international humanitarian law are war crimes and a subject to universal jurisdiction. War crimes can be committed by civilians, private contractors or by military force, however, for PMCs these laws apply if the state has adopted legislation enabling them to prosecute persons under the universal jurisdiction for war crimes. Many trials have taken place regarding this matter, but almost none yet for any PMC member mainly because of the messiness and unwillingness between states and because of avoiding expenses insuring witnesses from abroad.

However, there are two aspects for which a PMCs member can report and answer a war crime:

- Command Responsibility - if they have ordered or been informed of the crime they or their subordinates commit and did nothing to prevent. If there is no hierarchy of responsibilities within the PMC, then the question is who would. If a similar case appears within any state official, the International Criminal Tribunal can identify the case by the DE FACTO control as the case in the Former Yugoslavia (ICTY). This is not the case with hiring a PMC because the practice actually shows that the superior does not need to know of such violations and crimes and does not have to be guilty by virtue of command responsibility.

- Superior Orders - makes the subordinate responsible if he knew of a crime being committed. In this case, the soldier can use this as a defense if the superior has given him the order, but this case is not been present in some time. Whether this applies entirely to PMCs, is questionable because there is no precedent answer to this.

\section{CONCLUSION}

The globalization of the world economy and the reduction of the regular armed forces of States, in developed and developing countries, are some of the causes behind the rapid development of the privatization of violence. Classical interstate wars with clear front lines have almost disappeared. Instead, we witness low intensity armed conflicts; a widespread 
use of light weapons; and the privatization of military functions and asymmetry of the parties in the conflict. Private military and security companies are more and more performing a number of military functions. In many instances, they are managed by former militaries, are efficient and have a modern structure which characterizes for offering multiple services. Their participation has mushroomed in low intensity armed conflicts or post conflict situations such as in Afghanistan and Iraq employing "private security guards" who are heavily armed but with an ambiguous status permitting them to provide passive protection in situations and conflicts where there are no front lines and where the line between passive and active confrontation is extremely thin. There are a number of international instruments, which indirectly may be invoked with regard to the activities carried out by private military and security companies, the 1989 International Convention against mercenaries being one of them. There is, however, no international instrument, which regulates and monitors the military and security activities of these transnational companies. The only direct international form of regulation is the one which relates to the contract, which private military and security companies sign either with the government department outsourcing some of its functions, the international governmental organization, NGO, firm or individual which contracts them. They define the scope and scale of their activities as well as the rules of engagement. Those contracts, however, are private and kept confidentially.

Guaranteeing security, public order and respect for law and order and human rights are State obligations. Foreign policy is subject to international law, whether it is carried out by state organs or by private agents: States cannot avoid their international obligations merely because an activity is conducted by a private actor. States may contract these companies in attempts to avoid direct legal responsibilities. The fact that a State contracts and delegates its functions to private entities does not change its responsibility. International and constitutional law assign the task of security, public order and defense to the military and police forces under the concept of sovereignty and the monopoly of the use of force. If the state fails to show due diligence in preventing and responding to human rights violations committed by private actors, such abuses can give rise to state responsibility under international human rights law.

There is a lack of regulations at the international, regional and national levels regarding private military and security companies which often operate without effective oversight and accountability. Weak or insufficient domestic legislation, regulation and control of private military and security companies encourage these transnational companies to seek to recruit former military personnel and ex policemen from other developing countries, where labor is cheaper, as "security guards" in low-intensity armed conflicts.

Based on what was presented, do hiring PMCs, in the case Blackwater, help or harm?

From the point that PMCs, including Blackwater, were already specialized and well trained in logistics, specialized training, it helped the government function together stronger. Guarding and helping the U. S. military, in a way, Blackwater or any other PMC would do the job better and would save the other military army force perform their combat tasks.

In conclusion, it is possible to assert that the process of legitimization that the majority of PMSs are undertaking deepens the complexity that is already embedded into the issue of privatized security. PMSCs represent a hybrid actor, which draws its legitimacy both from the market and from other international actors and - more importantly - that is capable of adapting to different norms, but also to shape them in their favor. It is precisely because of this flexible and mutating nature that makes it impossible to give a definitive statement about whether or not their presence in a variety of security scenarios will be beneficial or detrimental to international politics.

This thesis attempted to make a modest contribution in showing the evolution of these actors in a limited time frame; it might be an initial step to understand not only where PMSCs are going but also how is it possible to legitimize even further their activities, maximizing the benefits and reducing the risks of their work.

\section{Bibliography}

[1] Abrahamsen, Rita, William, Michael c, "The Globalization of Private Security”.ISP/NSC Briefing Paper 05/02, London, Chatman House, (October 2005).

[2] Adams, Thomas. "The New Mercenaries and the Privatization of Conflict," Parameters, Vol. 29, 2 (Summer 1999)

[3] Avant, Deborah. 'The Privatization of Security and Change in the Control of Force', International Studies Perspectives, 2 (2004), 153-157; William Reno. 'The New Role for Private Armies in Inter-State"PeaceMaking" Relations', International Politics, Vol. 37, 1 (2000). 
[4] Benson, Bruce.L., "The Market for Force", The Independent Review,Vol. XI, N. 3, (Winter 2007)

[5] Berger, Peter. 'Holy War Inc: Inside the secret World of Osama Bin Laden (New York: Simon and Schuster, 2002)

[6] Bjork \& Jones. 'Overcoming Dilemmas Created by the 21st Century Mercenaries: Conceptualising the use of private security companies in Iraq', Third World Quarterly, Vol. 26, 4 (2005).

[7] Brooks, Doug. "Messiahs or Mercenaries? The Future of International Private Military Services".International Peacekeeping, 7:4 (2000) pp.129-144

[8] Bryden, Alan. 'Approaching the Privatisation of Security from a Security Governance Perspective', Private Actors and Security Governance, eds. Bryden and Caparini (London: DCAF \& Global Book Marketing, 2006).

[9] Campbell, Alastair. 'Mercenaries, Misfits or Misunderstood?' The World Today, Vol. 63, 12 (Dec., 2007).

[10] Cilliers \& Mason. Peace, Profit or Plunder? The Privatisation of Security in War-Torn African Societies (Halfway House: Institute of Security Studies, 1999).

[11] Croft \& Dunn. 'The impact of the Defence budget on arms control policy', in Hoffmann (ed.) The UK Arms Control Policy in the 1990s (Manchester University Press, 1990).

[12] Duffield, Martin. Global Governance and the New Wars (London: Zed Books, 2001).

[13] Edmunds, T. 'What are Armed Force For? The Changing Nature of Military Roles in Western Europe', International Affairs, Vol. 82, 6 (2002).

[14] Gaston, E.L.,"Mercenarism 2.0? The Rise of the Modern Private Security Industry and Its Implications for International Humanitarian Law Enforcement". Harvard International Law Journal, Vol.49, N.221, (2008)

[15] Ghebali, Victor-Yves. 'The United Nations and the Dilemma of Outsourcing Peacekeeping Operations' in, Private Actors and Security Governance, eds. Bryden \& Caparini $(2006)$.

[16] Holmquist, C. 'Private Security Companies. The Case for Regulation', SIRI Policy Paper, No. 9 (January 2005).

[17] Isenberg, David. A Fistful of Contractors: The Case for a Pragmatic Assessment of Private Military Companies in Iraq (London: British American Security Information Council, 2004)

[18] Johnson, James Turner, "Can Modern War Be Just? Connecticut, Yale University Press, (1984).

[19] Kassebaum, David. 'A Question of Facts -The Legal Use of Private Security Firms in Bosnia' Columbia Journal of Transnational Law, Vol. 38, 3 (2000)

[20] Kinsey, Christopher, "Corporate Soldiers and International Security: The Rise of Private Security Companies", London, Routledge, 2006

[21] Krahmann, Elke, "Regulating Private Military Companies: What Role for the EU?" Contemporary Security Policy, Vol.26, N.1 (2002)

[22] Krahmann, Elke. 'Conceptualizing Security Governance', Cooperation and Conflict, Vol. 38, 5 (2005).

[23] Kwakwa, e. Edward, "The Current Status of Mercenaries in Armed Conflict". Hastings International and Comparative Law Review, Vol.14 (1990)

[24] Layeb, E, "The Need for an International Convention Against Mercenaries and Mercenarism". African Journal of International and Comparative Law, Vol.1 (1989)

[25] Leander, Anna. 'The Market for Force and Public Security: The Destabilizing Consequences of Private Military Companies', Journal of Peace Research, Vol. 42, 5 (Sep., 2005)

[26] Lynch, Tony, Walsh, A.J, "The Good Mercenary?", The Journal of Political Philosophy, Vol.8, N,2 (2000)

[27] Mandel, Robert." The Privatization of Security. Armed Forces and Society, Vol.28, N.1 (2001)

[28] Matthieu \& Deardren. 'Corporate Mercenaries: The Threat of Private Military \& Security Companies' Review of African Political Economy, Vol. 34, 114 (Dec., 2007).

[29] Matziorinis, Nicholas; Nalin, Paolo; "Private Military Companies: Legitimacy and Accountability"; McGill Management; Montreal; (2004)

[30] Metz, Stephen. 'Armed Conflict in the Twenty-first Century: The Information Revolution and Postmodern Warfare, Strategic Studies Institute report' (Carlisle, Pa.: U.S. Army War College, April 2000)

[31] Morgan, Oliver. 'Soldiers of fortune hit the jackpot', The Observer (26th October, 2003.)

[32] Musah, Abdel-Futau. 'Privatization of Security: Arms Proliferation and the Process of State Collapse in Africa', Development and Change, Vol. 33, 5 (2002)

[33] Muthien \& Taylor, 'The Return of the Dogs of War', The Emergence of Private Authority in Global Governance, eds. Hall \& Biersteker (Cambridge: Cambridge University Press, 2002). 
[34] O' Brien, Kevin, "What should and should not be regulated?", in Simon Chesterman and Chia Lehnardt, eds, "From Mercenaries to Markets: The Rise and Regulation of Private Military Companies", Oxford: Oxford University Press, (2007)

[35] Percy, Sarah. 'Strong Norm, Weak Law', International Organization, Vol. 61, 2 (Spring, 2007)

[36] Reno, William. Warlord Politics and African States (London: Lynne Rienner, 1998);

[37] Richards, Paul. 'War as Smoke and Mirrors: Sierra Leone 1991-2, 1994-5, 1995-6', Anthropological Quarterly, Vol. 78, 2 (Spring, 2005)

[38] Robert H. Jackson, Quasi-states: Sovereignty, International Relations, and the Third World (New York: Cambridge University Press, 1990).

[39] Ross, Andrew L."Arms Acquisition and National Security: The Irony of Military Strength," in National Security in the Third World: The Management of Internal and External Threats, eds., Edward E. Azar \& Chun-in Moon, (Hants, Nova Scotia: Edward Elgar, 1988).

[40] Schreier \& Caparini, 'Privatising Security: Law Practice and Governance of Private Military and Security Companies', Geneva Centre for the Democratic Control of Armed Forces, Occasional Paper No. 6 (March, 2005).

[41] Shearer, David. 'Outsourcing War', Foreign Policy, 112 (autumn, 1998).

[42] Singer, Peter. 'Corporate Warriors :The Rise and Ramifications of the Privatized Military Industry', International Security, 26 (2001/02)

[43] Singer, Peter. 'War, Profits and the Vacuum of Law: Privatized Military Firms and International Law', Colombia Journal of Transnational Law, Vol. 42, 2 (2004).

[44] Singer, Peter Warren, "Corporate Warriors - The Rise of the Privatized Military Industry and its Ramifications for International Security", International Security, Vol.26, N.3 (Winter 2001-02), pp.186-220

[45] Spicer, Tim, "Interview", Cambridge Review of International Relations, Cambridge, Vol. XIII, No.1, (1999)

[46] Spicer, Tim, "An Unorthodox Soldier: Peace and War and the Sandline Affair".Edinburgh, Mainstream, (1999).

[47] Strange, Susan. The Retreat of the State: The Diffusion of Power in the World Economy (1996)

[48] Suter, Keith. 'Mercenaries, Mines and Mistakes', The World Today, Vol. 53, 11 (Nov., 1997)

[49] Thompson, Janice,"Mercenaries, Pirates, and Sovereigns: State Building and Extraterritorial Violence in Early Modern Europe". Princeton, N.J., Princeton University Press, (1994)

[50] Training of Mercenaries, International Legal Materials, Vol. 29, 1 (Jan., 1990).

[51] United Nations International Convention Against the Recruitment, Use, Financing and Training of Mercenaries

[52] Walker \& Whyte. 'Contracting Out War? Private Military Companies, Law and Regulation in the United Kingdom', International \& Comparative Law Quarterly, Vol. 54, 3 (2005).

[53] Waltz, Kenneth N. 'Man, the State and War: A Theoretical Analysis', (Columbia University Press: Columbia, 1959)

[54] Weber, Max. The Vocation Lectures, 'Politics as a Vocation' (Indianapolis: Hackett Publishing Co., 2004)

[55] Weiss, Robert P. 'From Cowboy Detectives to Soldiers of Fortune: Private Security Contracting and Its Contradictions on the New Frontiers of Capitalist Expansion', Social Justice, Vol. 34, 3 (2007).

[56] Whyte, D. Lethal Regulation: State-Corporate Crime and the United Kingdom's New Mercenaries, Journal of law and Society, Vol. 30, 4 (Dec., 2003).

[57] Wight, Martin. Power Politics, eds. Bull \& Holbrand, (Leister University Press: Leister, 1995) 